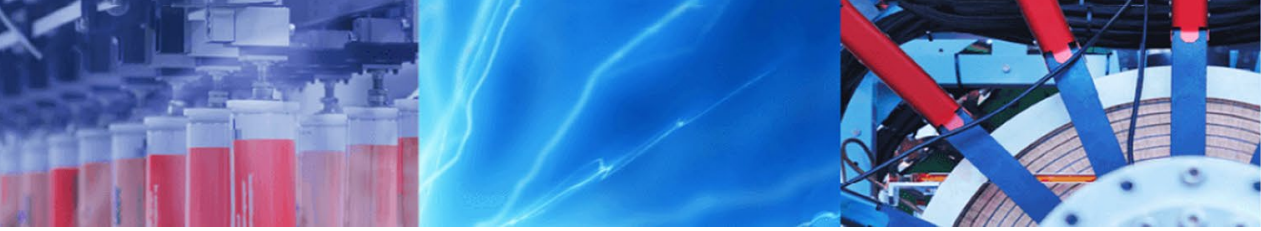

Research Article

\title{
Biochemical characterization of irradiated soybean and nutritional and sensory evaluation of water-soluble soybean extract
}

\author{
Érica Amanda de Barros ${ }^{1}$. Vladimir Eliodoro Costa ${ }^{1}$. Dayanne Fabrício Bressan ${ }^{1}$. \\ Renata Bruna dos Santos Coscolin ${ }^{1} \cdot$ Rogério Lopes Vieites $^{2} \cdot$ Fernando Broetto $^{1}$ (i)
}

Received: 30 July 2019 / Accepted: 1 November 2019 / Published online: 7 November 2019

(c) Springer Nature Switzerland AG 2019

\begin{abstract}
The techniques used for the preservation and processing of foods can interfere with their nutritional and organoleptic quality. The objective of this study was to evaluate the antioxidants of irradiated soybean cultivars and to determine the most suitable method of processing of water-soluble soybean extract (WSE) from their nutritional and sensory characterization. Different soybean cultivars irradiated with doses of 2, 4 and $8 \mathrm{kGy}$ were submitted to biochemical analysis. The WSEs were produced by hot and cold extraction and subjected to physicochemical, biochemical, microbiological and sensory analyses. Phenolic compounds increased in the cultivars irradiated with the dose of $4 \mathrm{kGy}$ or higher. However, flavonoid content, antioxidant capacity and oxidant/antioxidant enzymes remained stable regardless of the irradiation dose, except for SOD of cultivar BRS-213 whose activity was reduced at the dose of $8 \mathrm{kGy}$. Sensory acceptance was obtained for the WSE produced by hot extraction but not by cold extraction, while the latter exhibited higher protein and lipid content.
\end{abstract}

Keywords Soybean $\cdot$ Gamma radiation $\cdot$ Integral juice $\cdot$ Antioxidant activity $\cdot$ Extraction methods

\section{Introduction}

Soybean is a globally important legume crop because of its socioeconomic impact, and Brazil is the one of the largest producers. Furthermore, soy and its derivatives are known as functional foods due to their various health benefits [1]. This characteristic is mainly attributed to the presence of proteins and phytochemicals (isoflavones, tocopherol, phytosterols), compounds with an elevated antioxidant potential that prevent the formation of reactive oxygen species. Soy products are investigated as foods to reduce the risk of breast and prostate cancer, osteoporosis, cardiovascular diseases and postmenopausal symptoms, as well as serum cholesterol and triglycerides levels [2].
Soybean oilseeds exhibit great versatility as a raw material in the processing of foods due to their composition, permitting the production of tasty and easily digestible products. Compared to soy products, soy milk has become popular as a beverage derived from a healthy food [3]. However, Ma et al. [4] suggested Western and Chinese consumers to have different preferences for the flavor attributes of water-soluble soybean extract (WSE) due to their different eating habits, which will depend on the chemical composition of soybeans and the processing technique. It is therefore necessary to adapt the possible processing techniques of different soybean cultivars in order to improve the acceptance of this beverage in each country.

The growing demand of the population for healthy foods has boosted research aimed at developing new

\footnotetext{
$\triangle$ Fernando Broetto, fernando.broetto@unesp.br| ${ }^{1}$ Institute of Biosciences - IBB-Botucatu, São Paulo State University (UNESP), Campus of Botucatu, Street Profa Dra Irina Delanova Gemtchujnicov, Botucatu, SP 18618-693, Brazil. ${ }^{2}$ Faculty of Agronomic Sciences, São Paulo State University (UNESP), Lageado Farm, Ordinance I: Street José Barbosa de Barros, n 1780, Botucatu, SP 18.610-307, Brazil.
} 
technologies designed to improve or maintain the nutritional value of a food without losses in sensory quality, in addition to providing a safe product for consumers with minimal generation of environmentally harmful waste [5]. Thermal treatments are the most commonly used methods to extend the shelf life of beverages, eliminating microorganisms and inactivating enzymes. However, the heat causes irreversible losses of nutritional components and undesired alterations in physicochemical properties and antioxidant compounds [6]. Thus, the advantage of non-thermal technologies should be highlighted, which are essential to obtain food products with little nutrient loss. In this respect, ionizing irradiation administered at the appropriate dose for a given food or beverage interferes minimally with its sensory and nutritional characteristics [7].

With the advances in food preservation technologies, it was observed more than half a century ago that gamma radiation from ${ }^{60} \mathrm{Co}$ or ${ }^{137} \mathrm{Cs}$ or even accelerated electron beams can inhibit the proliferation of pathogenic microorganisms that can cause severe diseases in the population [8]. In addition to the inhibition of microorganisms, gamma radiation can interact with some molecules found in foods. In the literature, there are numerous studies on radiation, for example De Barros et al. [9] and Popovic et al. [1] detected a reduction of up to $70 \%$ in lipoxygenase activity in a Brazilian soybean cultivar and an increase in antioxidant capacity in Serbian soybeans, respectively, both irradiated with $10 \mathrm{kGy}$.

Industries seek new market opportunities and tend to diversify their products, developing new foods and reinforcing their sensory, nutritional and functional attributes [10]. In this respect, the objective of this study was to evaluate the antioxidants of irradiated soybean cultivars and to determine the most appropriate method of processing EHS. Specifically, the trial aimed to select the soybean cultivar through the gamma radiation dose that induced increase in its antioxidants and lower oxidative potential. In addition, we sought to determine the most suitable method for processing EHS from its nutritional and sensory characterization.

\section{Materials and methods}

\subsection{Material}

The soybeans used in phase 1 were specific for culinary use, and all of them were provided by EMBRAPA Soybean (Brazilian Agricultural Research Corporation), Londrina, Paraná, Brazil. The following EMBRAPA soybean cultivars were used in the assays: BRS-213 (lipoxygenases free) and BRS-258 and Embrapa-48 (EMB-48), both producing lipoxygenases. Lipoxygenases are enzymes that can catalyze reactions that add unpleasant tastes and aromas to soy products, but these enzymes are inactivated by heat treatment. [11].

In phase 2, clarified apple juice concentrate, produced by Tecnovin do Brasil Ltda. (Bento Gonçalves, RS), was used to sweeten the WSEs. The extracts were supplemented with acacia/Arabic gum, guar gum and carboxymethylcellulose as additives to improve the stabilizing potential of proteins present in the beverage. Vanilla essence and antioxidants (ascorbic acid and tocopherol) were also added.

\subsection{Methods}

\subsubsection{Grain irradiation (phase 1)}

The soybeans were irradiated with a Cobalt ${ }^{60}$ Multipurpose Irradiator of Nuclear and Energy Research Institute, localized in São Paulo, Brazil. The activity and dose rate of the source used were $8.76 \mathrm{PBq}$ (measured in November 2016) and $5.5 \mathrm{kGy} / \mathrm{h}$, respectively. The three soybean cultivars were irradiated with four different doses of gamma rays $(0,2,4$ and $8 \mathrm{kGy})$, where 0 is the control (no irradiation). Three recipients with the corresponding cultivars were prepared per irradiation dose. The experiment was conducted in a $4 \times 3$ factorial scheme, with four variables per cultivar and three replicates, totaling 36 experimental units.

Based on the best biochemical results obtained, only one soybean cultivar and one gamma radiation dose were chosen for subsequent preparation of the WSE.

\subsubsection{Production techniques of WSE (phase 2)}

Soybean cultivar BRS-213 (non-irradiated) was used for the production of the WSEs using two processing methods: traditional method-cold extraction [12] and modified Illinois method-hot extraction [13]. Both extracts were prepared at a proportion of 1:6 (soybean:water), with extraction basically consisting of immersion of the grains in water (maceration), trituration, filtration, cooking and adjustment of the final volume [13].

Pre-tests were conducted to adjust the amounts of some of the additives used, except for those with limits pre-established by the legislation. Thus, after the WSE was obtained with the two methods, the beverages were supplemented with 3\% acacia/Arabic gum, 1\% neutral binder (guar gum and carboxymethylcellulose), 0.2\% vanilla essence and $0.05 \mathrm{~g} 100 \mathrm{~mL}^{-1}$ each of tocopherol and ascorbic acid. The WSE was sweetened with apple juice concentrate. The additives were homogenized in an industrial blender. 
Traditional method (cold extraction of WSE) Soybeans $(166.67 \mathrm{~g})$ were kept in a glass beaker $(2 \mathrm{~L})$ with distilled water $(833.35 \mathrm{~mL})$ at a proportion of 1:5 (soybean:water) for $14 \mathrm{~h}$. The maceration water was discarded, and the grains were triturated for approximately $1 \mathrm{~min}$ in a blender with cold distilled water $(1000 \mathrm{~mL})$ at a proportion of 1:6 (soybean:water). The soybean paste obtained after trituration was filtered through a cloth strainer, separating the okara from the WSE. Next, the extract was transferred to an aluminum milk can and heated to $90 \pm 5^{\circ} \mathrm{C}$ for $15 \mathrm{~min}$ in an industrial oven. Maintenance of the temperature was controlled with a food thermometer. The WSE was produced as proposed by Howell and Caldwell [12], with modifications. This method was repeated three times.

Illinois method (hot extraction of WSE) Soybeans (166.67 g) were transferred to an aluminum milk can containing boiling distilled water $(833.35 \mathrm{~mL})$ at a proportion of 1:5 (soybean:water) for whitening of the grains $\left(90 \pm 5^{\circ} \mathrm{C}\right)$ for $15 \mathrm{~min}$ in an industrial oven. The temperature was monitored with a food thermometer. Next, the whitening water was discarded and the grains were triturated for approximately $1 \mathrm{~min}$ in a blender with boiling water $(1000 \mathrm{~mL})$ at a proportion of 1:6 (soybean:water). The soybean paste obtained by trituration was filtered through a cloth strainer, separating the okara from the WSE. The extract was produced as described by Nelson et al. [13].

The WSEs were sweetened to a concentration of $14^{\circ}$ Brix with clarified apple juice concentrate [14]. The following mass balance equation was used to correct for soluble solids:

$S_{1} \cdot M_{1}+S_{2} \cdot M_{2}=S_{3} \cdot M_{3}$

where $S_{1}=$ soluble solids of the initial WSE; $M_{1}=$ mass of the initial WSE; $S_{2}=$ soluble solids of apple juice concentrate used for correction; $M_{2}=$ mass of juice used for correction; $S_{3}=$ soluble solids of the final WSE; $M_{3}=$ mass of the final WSE.

\subsection{Analyses}

\subsubsection{Biochemical parameters}

Superoxide dismutase-SOD: $100 \mu \mathrm{L}$ crude enzyme extract, $3 \mathrm{~mL}$ of a solution with $13 \mathrm{mM} \mathrm{L-methionine,} 2 \mu \mathrm{M}$ riboflavin, $75 \mu \mathrm{M}$ p-nitro-tetrazolium chloride (NBT) and $100 \mathrm{nM}$ EDTA, in buffer $50 \mathrm{mM}$ sodium phosphate, pH 7.8. The reaction took place in a chamber, under the illumination of a $15 \mathrm{~W}$ fluorescent lamp, kept inside a box covered with aluminum foil at $25^{\circ} \mathrm{C}$. The reaction was stopped 5 min later by turning off the lamp. SOD activity was measured by the difference in increasing absorbance of the samples at $560 \mathrm{nM}$, subtracted from a "blank" to which the crude enzyme extract was not added. One unit of SOD was defined as the amount of enzyme needed to inhibit NBT photoduction by $50 \%$ [15].

Peroxidase-POD: $100 \mu \mathrm{L}$ of crude sample extract was added with $4.9 \mathrm{~mL}$ of $25 \mathrm{mM}$ potassium phosphate buffer solution, pH 6.8 containing $20 \mathrm{mM}$ pyrogallol and $20 \mathrm{mM} \mathrm{H}_{2} \mathrm{O}_{2}$. After incubation for $1 \mathrm{~min}$, the reaction was quenched with $0.5 \mathrm{~mL} \mathrm{H}_{2} \mathrm{SO}_{4}$ (5\%). The absorbance reading was taken at $420 \mathrm{nM}$; molar extinction coefficient of $2.47 \mathrm{mM}^{-1} \mathrm{~cm}$ was used to calculate specific activity [16].

Polyphenol oxidase-PPO: To the test tube were added $0.3 \mathrm{~mL}$ of enzyme extract and $1.85 \mathrm{~mL}$ of $0.1 \mathrm{~N}$ catechol. The vials were kept in a water bath at $30{ }^{\circ} \mathrm{C}$ for $30 \mathrm{~min}$. Then, $0.8 \mathrm{ml}$ of $2 \mathrm{~N}$ perchloric acid was added for further reading of the samples at $395 \mathrm{nM}$ [17].

The analyses performed for both irradiated soybean and EHS were as follows:

Phenolic compounds: $0.3 \mathrm{~mL}$ of aqueous extract of the sample, $0.7 \mathrm{~mL}$ of water, $0.5 \mathrm{~mL}$ of Folin-Ciocalteu reagent were transferred to a test tube, after $2.5 \mathrm{~min}$, $2.5 \mathrm{~mL}$ of $20 \%$ sodium. The tubes were left for $1 \mathrm{~h}$ in the absence of light for further reading on a $725 \mathrm{nM}$ spectrophotometer [18].

Flavonoids: $1 \mathrm{~g}$ of sample and $4 \mathrm{~mL}$ of acidified methanol ( $10 \%$ glacial acetic acid) were added to the tube. After centrifugation, $1 \mathrm{~mL}$ of aluminum chloride (5\%) was added to the supernatant. After $30 \mathrm{~min}$, in the absence of light, a spectrophotometer reading at $425 \mathrm{nM}$ was taken [19].

Antioxidant capacity: A $0.5 \mathrm{~mL}$ aliquot of the sample extract was added to $3 \mathrm{~mL}$ of $100 \%$ ethanol and $300 \mu \mathrm{L}$ of DPPH solution ( $0.5 \mathrm{mM}$ in ethanol). The absorbance measurement was at $517 \mathrm{nM}$. The result was expressed in equivalent $\mu$ moles of trolox per $100 \mathrm{~g}$ sample (TEAC $100 \mathrm{~g}^{-1}$ ) [20].

The analyses performed for the EHS were as follows:

Physicochemical parameters: Metabolizable energy (Kcal), moisture, total solids, proteins, lipids, ashes, $\mathrm{pH}$, acidity, soluble solids, carbohydrates, following the methodology established by the Adolfo Lutz Institute [21].

Color: The samples were subjected to the Konica Minolta colorimeter (Chroma meter, CR 400/410) in a wavelength range from 380 to $780 \mathrm{nM}$ [22].

Microbiological parameters: Microbiological analyses followed the methodologies described in Silva et al. [23]. The count of the results obtained was expressed in Colony-Forming Units per $\mathrm{cm}^{2}\left(\mathrm{CFU} / \mathrm{cm}^{2}\right)$, except for total and thermotolerant coliforms where the results 
were demonstrated by the most probable number (MPN) value per gram, through specific table.

Salmonella sp.: In the sample, tetrathionate broth was used for enrichment $\left(35-37^{\circ} \mathrm{C}\right.$ for $\left.24 \mathrm{~h}\right)$ and after that an aliquot was seeded by isolation on SS agar and XLD agar and incubated at $35-37^{\circ} \mathrm{C}$ for $24 \mathrm{~h}$.

Total coliforms: Sample dilutions were made in $225 \mathrm{~mL}$ of $0.1 \%$ buffered peptone water. Each dilution was seeded into three tubes containing lauryl sulfate tryptose (LST) broth, carried at $35^{\circ} \mathrm{C} / 48 \mathrm{~h}$ (presumptive test). The tubes that showed gas formation inside the Duran tubes were inoculated in $2 \%$ bright green bile lactose broth and incubated at $35^{\circ} \mathrm{C}$. Confirmation was with new carbon dioxide formation.

Thermotolerant coliforms: This analysis is similar to total coliforms until presumptive proof. Subsequently, the volume of the tube was inoculated into EC broth and incubated at $45^{\circ} \mathrm{C} / 24 \mathrm{~h}$ at $48 \mathrm{~h}$.

Bacillus cereus: Decimal dilutions of samples were performed and plated on Bacillus cereus agar plates. After incubation, it was at $30^{\circ} \mathrm{C} / 24 \mathrm{~h}$.

Staphylococcus aureus: $0.1 \mathrm{~mL}$ aliquots of the diluted sample tubes were pipetted, and the volume was plated with Baird-Parker medium and incubated at $37^{\circ} \mathrm{C} / 48 \mathrm{~h}$. Molds and yeasts: Diluted samples were seeded on Sabouraud agar medium with chloramphenicol. Incubation was at $25^{\circ} \mathrm{C}$ for 5 days.

Mesophilic bacteria: Diluted samples were seeded on nutrient agar by pour plate technique and incubated at $35^{\circ} \mathrm{C} / 24-48 \mathrm{~h}$.

\subsubsection{Sensory analysis}

The sensory properties of the WSE were evaluated after approval by the Ethics Committee on Research Involving Humans of Universidade Estadual Paulista "Júlio de Mesquita Filho," Botucatu, SP, Brazil (Approval No.: 16166713.6.0000.5411). This analysis was only performed when the microbiological count of the samples was between 0 and the limit established by the current legislation (RDC No. 12 of January 2, 2001).

An effective method was chosen for sensory evaluation, which consisted of acceptance testing on a hedonic scale and rating the attribute's intensity. The hedonic scale was represented by the following notes: 1 -disliked extremely, 2-disliked very much, 3-disliked moderately, 4-disliked slightly, 5-neither like nor dislike, 6-liked slightly, 7-liked moderately, 8-liked very much and 9liked extremely. Already the intensity scale ranged from much more intense than like (2), a little more intense than like (1), intense as I like (0), a little less intense than like $(-1)$ to much less intense than I like $(-2)$ [24]. The scores of the scales were used to evaluate the attributes of each sample. The samples were evaluated by 60 untrained and unselected panelists under white light. The samples were coded with three-digit numbers and randomized [25].The panelists consisted of employees and undergraduate and postgraduate students of the Botucatu Campus of UNESP. Each panelist received $30 \mathrm{~mL}$ of the cooled beverage $\left( \pm 4^{\circ} \mathrm{C}\right)$ in a transparent plastic cup.

\subsubsection{Statistical analysis}

The results of the physicochemical, biochemical, microbiological and sensory analyses are expressed as means. In phase 1, the Kruskal-Wallis test was used to compare the biochemical results between treatments since the data were not normally distributed. The $t$ test was used for analysis of the physicochemical and biochemical results of phase 2 when the two treatments (hot $x$ cold extraction) were compared. Descriptive statistics and the Wilcoxon test were used for sensory analysis [26].

\section{Results and discussion}

\subsection{Phase 1: Irradiated soybeans}

\subsubsection{Physicochemical analysis}

The content of phenolic compounds only differed between the soybean cultivars of the control treatment (Table 1), demonstrating that some parameters may vary between commercial soybean cultivars. This fact might be explained by differences in soil and climate characteristics and genotype variations, among others [27]. An increase in phenolic compounds with increasing irradiation dose (4 kGy and higher) was observed in the BRS-213 and BRS258 cultivars, which differed significantly from the $2 \mathrm{kGy}$ treatment and control. This condition could be related to the production of free radicals induced by oxidative stress in detriment to the preservation method, stimulating the secondary metabolism of the plant, specifically phenylalanine ammonia-lyase to catalyze the production of more antioxidants, like phenols [28].

Toledo et al. [29] observed a significant increase in phenolic compounds in BRS-213 soybeans irradiated with a dose of $8 \mathrm{kGy}\left(10.83 \mathrm{mg} \mathrm{g}^{-1}\right)$ compared to control $\left(8.07 \mathrm{mg} \mathrm{g}^{-1}\right)$, mean results that were lower than those found for the same cultivar in the present experiment (control: $12.4 \mathrm{mg} \mathrm{g}^{-1}$; $8 \mathrm{kGy}$ treatment: $15.2 \mathrm{mg} \mathrm{g}^{-1}$ ) (Table 1). However, the percent increase in phenolic compounds reported by Toledo et al. [29] was higher (34\%) than that found in this study (23\%). These authors pointed out that the $8 \mathrm{kGy}$ dose may have modified the molecular structure of insoluble phenolic compounds to soluble 
Table 1 Mean values followed by standard deviation $(n=3 \pm \mathrm{SD})$ of phenolic compounds (mg of phenols $\mathrm{g}^{-1}$ ), flavonoids ( $\mathrm{mg} \mathrm{g}^{-1}$ of phenols) and antioxidant activity $\left(\mu \mathrm{m} 100 \mathrm{~g}^{-1}\right)$ of each soybean cultivar (BRS-213, BRS-258 and Embrapa-48) submitted to different doses of gamma radiation $(2,4$ and $8 \mathrm{kGy}) .0$ represents nonirradiated samples (control)

\begin{tabular}{llllll}
\hline Determinations & Samples & \multicolumn{5}{l}{ Gamma radiation doses (kGy) } \\
\cline { 2 - 6 } & Soybeans cultivars & 0 & 2 & 4 & 8 \\
\hline Phenolic compounds & BRS-213 & $12.4 \pm 0.2 \mathrm{bB}$ & $13.4 \pm 1.2 \mathrm{ab}$ & $15.5 \pm 1.1 \mathrm{a}$ & $15.2 \pm 0.4 \mathrm{a}$ \\
& BRS-258 & $13.4 \pm 0.5 \mathrm{bAB}$ & $13.2 \pm 0.5 \mathrm{~b}$ & $14.0 \pm 0.1 \mathrm{ab}$ & $14.5 \pm 0.4 \mathrm{a}$ \\
& EMB-48* & $14.2 \pm 0.6 \mathrm{~A}$ & $14.1 \pm 0.9$ & $14.2 \pm 0.7$ & $15.0 \pm 0.9$ \\
Flavonoids & BRS-213 & $12.1 \pm 0.1$ & $12.5 \pm 0.3$ & $12.5 \pm 0.7$ & $13.6 \pm 0.5$ \\
& BRS-258 & $12.5 \pm 1.1$ & $12.1 \pm 1.2$ & $11.8 \pm 0.2$ & $12.9 \pm 0.7$ \\
Antioxidant activity & EMB-48* & $11.9 \pm 1.1$ & $13.1 \pm 0.4$ & $13.7 \pm 1.0$ & $13.3 \pm 0.5$ \\
& BRS-213 & $33.8 \pm 3.8$ & $35.4 \pm 2.6$ & $34.7 \pm 3.1$ & $34.3 \pm 2.3$ \\
& BRS-258 & $36.5 \pm 0.9$ & $35 \pm 1.9$ & $37.1 \pm 3.9$ & $30.2 \pm 0.5$ \\
& EMB-48* & $33.1 \pm 4.2$ & $29.8 \pm 1.4$ & $35.1 \pm 2.9$ & $36.1 \pm 2.2$ \\
\hline
\end{tabular}

Lowercase letters compare the differences between the doses (horizontal) of each determination; uppercase letters, vertically, compare the differences between cultivars for each dose received, from the Kruskal-Wallis test. Absence of letters showed that there was no significant difference. EMB-48*: cultivar Embrapa-48 compounds or has ruptured the cell wall, favoring detection of the compound.

The results showed that flavonoids account for the majority of phenolic compounds found in soybeans, with a mean flavonoid content of $89.83 \%, 89.44 \%$ and $90.4 \%$ in cultivars BRS-213, BRS-258 and Embrapa-48, respectively (Table 1). Similar results have been reported by LópezGutiérrez et al. [30] who detected an average of 93\% isoflavones (flavonoids) among phenolic compounds in soybean-derived products. These high percentages of flavonoids were expected since studies in the literature highlight the high isoflavone content of soybeans [31].

An increase in antioxidant capacity compared to control was observed for cultivars BRS-213, BRS-258 and Embrapa-48 irradiated with 2 kGy (4.73\%), 4 kGy (1.64\%) and $8 \mathrm{kGy}(9.06 \%)$, respectively (Table 1). Although this increase in antioxidant capacity was not significant, these results agree with Dixit et al. [2] who showed that irradiation with doses of 0.5 and $2 \mathrm{kGy}$ induced a progressive increase in the antioxidant capacity of the three soybean cultivars, while a decrease was observed at a dose of $5 \mathrm{kGy}$. Similarly, Popović et al. [1] observed a gradual increase in antioxidant capacity when they submitted a Serbian soybean cultivar to gamma radiation with doses of 1,2, 4 and 10 kGy.

\subsubsection{Biochemical analysis}

Increasing the gamma radiation dose did not cause significant changes in the enzymes analyzed (SOD, PPO and POD) in the three soybean cultivars (BRS-213, BRS-258 and Embrapa-48), except for SOD of cultivar BRS-213. A significant difference in the activity of this enzyme was observed when the dose was increased from 2 and $4 \mathrm{kGy}$ to $8 \mathrm{kGy}$ (Fig. 1). Comparison to the control showed a percent increase in SOD activity of $1 \%$ at the dose of $2 \mathrm{kGy}$ and of $16 \%$ at $4 \mathrm{kGy}$, while the activity of this enzyme was reduced by $5 \%$ at $8 \mathrm{kGy}$. This inhibition of SOD at the dose of $8 \mathrm{kGy}$ is probably related to denaturation of the structure of the enzyme due to the time of exposure to gamma rays [32].

Tewari et al. [33] analyzed antioxidant enzymes (SOD, catalase and POD) and found no significant differences when increasing the irradiation dose $(0.25,0.5$ and $1 \mathrm{kGy})$ in four soybean cultivars (BR-2, BS-1, Pk-416 and Bragg). Similar findings were obtained in the present study for SOD (cultivars BRS-258 and Embrapa-48) and POD (all cultivars), demonstrating that these enzymes are stable in these soybean cultivars when exposed to a gamma radiation dose of up to $8 \mathrm{kGy}$ (Fig. 1). In contrast, Alikamanoglu et al. [34] observed a reduction in SOD and POD activity with increasing irradiation dose $(0.1,0.2,0.3,0.4$ and $0.5 \mathrm{kGy}$ ) in a Turkish soybean cultivar, suggesting that the enzymes of each soybean cultivar may react differently to gamma radiation.

The need to quantify POD and PPO is given by the known impact of these enzymes on the food industry. These enzymes are oxidoreductases that catalyze oxidative reactions in plants. In this respect, POD is responsible for changes in flavor during storage and PPO induces changes in the color of foods [35]. Thus, the fact that a dose increase does not significantly interfere with the activity of these enzymes characterizes gamma radiation as an advantageous preservation method because it does not increase the activity of either enzyme (Fig. 1). A significant difference in POD activity between soybean cultivars was only observed at the dose of $4 \mathrm{kGy}$. Comparison of the activity of the other enzymes between soybean cultivars at each irradiation dose revealed that no significant difference was found (Fig. 1). 

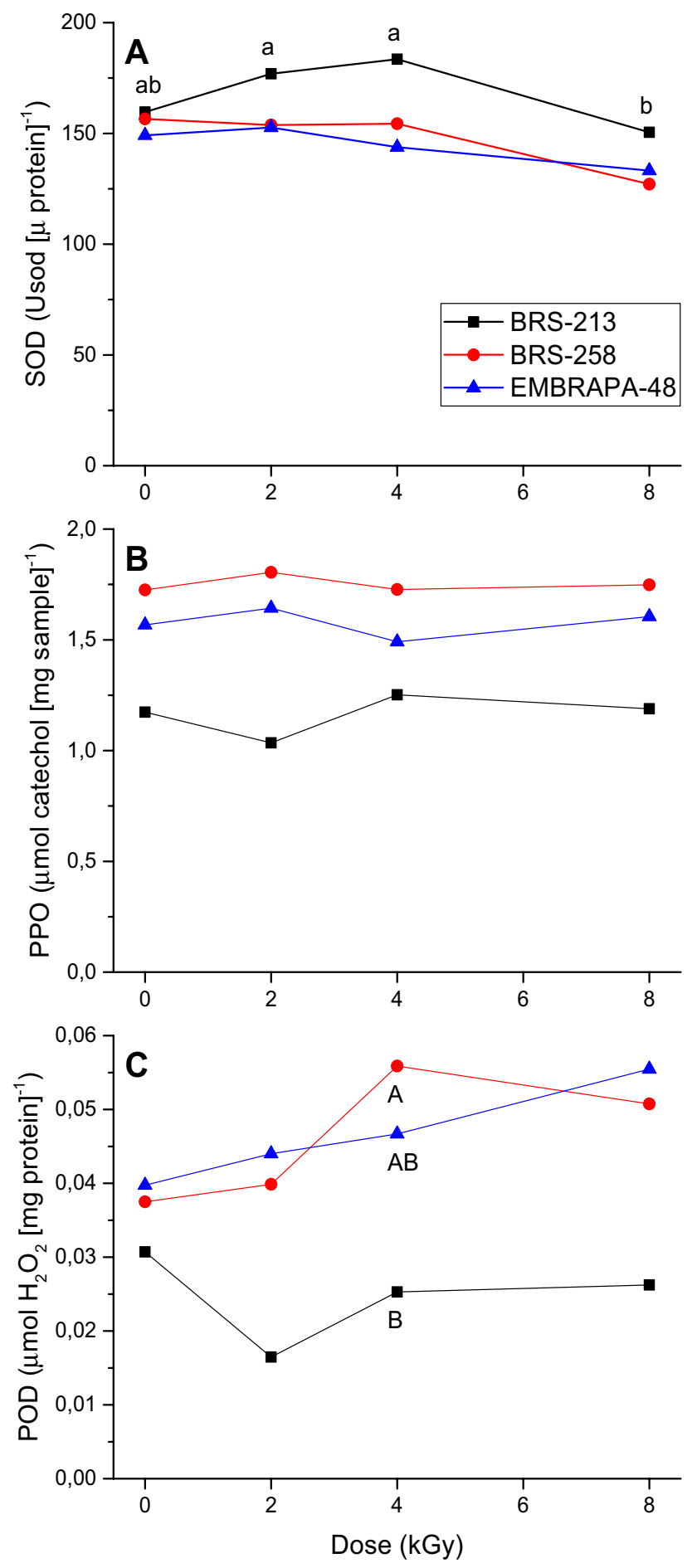

Fig. 1 Enzymatic activity of soybean cultivars BRS-213, BRS-258 and Embrapa-48 irradiated with doses of 2, 4 and $8 \mathrm{kGy}$, with $0 \mathrm{kGy}$ not irradiated. Enzymes: a superoxide dismutase-SOD; $\mathbf{b}$ polyphenoxidase-PPO, c peroxidase-POD. Lowercase horizontal letters compare the differences between doses for each cultivar; vertical letters compare the differences between cultivars for each dose from the Kruskal-Wallis test
Table 2 Mean results followed by standard deviation $(n=3 \pm S D)$ of the physical-chemical composition of WSE produced by the cold and hot extraction method

\begin{tabular}{|c|c|c|}
\hline \multirow{2}{*}{ Methods } & \multicolumn{2}{|c|}{ Extraction method } \\
\hline & Cold & Hot \\
\hline Calorie (Kcal) & $66.19 \pm 012 \mathrm{a}$ & $57.98 \pm 0.44 b$ \\
\hline Moisture (\%) & $85.07 \pm 0.21$ & $85.12 \pm 0.17$ \\
\hline Ashes (\%) & $0.61 \pm 0.03$ & $0.51 \pm 0.07$ \\
\hline Total solids (\%) & $14.93 \pm 0.21 \mathrm{a}$ & $14.88 \pm 0.17 b$ \\
\hline Soluble solids ('Brix) & $14.03 \pm 0.21$ & $14.07 \pm 0.06$ \\
\hline $\mathrm{pH}\left(\mathrm{g} 100 \mathrm{~mL}^{-1}\right)$ & $5.16 \pm 0.08 a$ & $4.79 \pm 0.04 b$ \\
\hline Acid. (g $100 \mathrm{~mL}^{-1}$ ) & $0.36 \pm 0.05$ & $0.35 \pm 0.05$ \\
\hline Lipids (\%) & $1.78 \pm 0.12 \mathrm{a}$ & $0.9 \pm 0.09 \mathrm{~b}$ \\
\hline Proteins (\%) & $2.6 \pm 0.03 a$ & $1.25 \pm 0.46 b$ \\
\hline Carbohydrates (\%) & $9.94 \pm 1.28 b$ & $11.23 \pm 0.97 a$ \\
\hline
\end{tabular}

Different lowercase letters between the methods indicate significant difference from the $t$ test

Since the results of biochemical analysis were similar among the soybean cultivars and did not differ with increasing irradiation dose, cultivar BRS-213 was selected for the production of WSE in the next phase. In addition, this cultivar is free of lipoxygenases (isoenzymes that act on polyunsaturated fatty acids generating offflavors) [36].

The different irradiation doses did not interfere with most of the biochemical compounds and did not result in relevant improvement in the nutritional quality of the soybean cultivars tested. Thus, the results did not indicate the need to irradiate soybeans for the production of WSE.

\subsection{Phase 2: Production of water-soluble soybean extract-WSE (hot and cold extraction)}

\subsubsection{Physicochemical analysis}

Macronutrients (proteins, lipids and carbohydrates) differed significantly between the hot and cold extraction methods (Table 2). These findings show that, despite the use of the same soybean:water proportion (1:6) and the same soybean cultivar (BRS-213) in the two processing techniques, the centesimal composition differed between the WSEs obtained, i.e., these characteristics depend on the method used for production of the beverage [37].

Regarding the parameters that differed significantly between treatments, higher percentages were observed for the WSE produced by cold extraction, demonstrating that it is a nutritionally richer beverage than that produced by hot extraction. Thus, since metabolizable energy was calculated from macronutrients, it was higher for WSE obtained by cold extraction (Table 2). 
Only the concentration of carbohydrates was lower in the WSE produced by cold extraction (9.94\%) compared to that produced by hot extraction (11.23\%). These carbohydrates mainly comprise the sugars of the apple juice concentrate added for sweetening the beverages, since WSE contains traces of non-metabolizable oligosaccharides such as raffinose $(0.012 \%)$ and stachyose $(0.064 \%)$ and only $0.12 \%$ sucrose and $1.5 \%$ other carbohydrates such as galactose, glucose, fructose and verbascose [38]. Thus, because the WSEs were standardized to $14^{\circ}$ Brix of soluble solids, mass balance calculation showed the need to add a larger amount of apple juice concentrate to the beverage produced by hot extraction since it is poor in nutrients, i.e., its soluble solid content is lower than that of WSE produced by cold extraction (Table 2 ).

Color analysis indicated that from the $a^{*}$ and $b^{*}$ index and independent of the EHS production method, the samples showed greenish yellow color (Table 3). The contribution of green was very small, close to zero, and was confirmed by the value of ${ }^{\circ}$ Hue (approximately $90^{\circ}$ ) indicating the yellow color for the samples. These findings were due to the characteristic color of the soybean cultivar and apple juice concentrate added to the WSEs.

Some factors can interfere with the color of beverages, particularly the additives used for their production. Nunes et al. [39] analyzed commercial yogurt soy drink flavored with strawberry pulp and found lower lightness values $(L=65)$ than those observed in this experiment (Table 3 ). In this respect, the addition of strawberry pulp rendered the beverage darker. Another important factor that can also affect the color of WSE is the soybean:water proportion, which results in a more or less diluted beverage.

WSE produced by cold extraction had greater lightness. Thus, this method provided a clearer extract than hot extraction. This result is confirmed by the lower Chroma value obtained for WSE obtained by cold extraction, indicating that this extract is less saturated, i.e., has a lighter color than WSE obtained by hot extraction (Table 3). A possible reason for the higher saturation (Chroma) of the WSE obtained by hot extraction was its higher content of apple juice concentrate, which has a dark, caramelized sugarlike color. WSE produced by cold extraction exhibited a higher protein and lipid content when compared to the other method (Table 2), substances that confer turbidity to the beverage and therefore interfere with color. However, the percentages of these compounds were not as relevant as the color resulting from the clarified apple juice, considering the difference in lightness and Chroma between treatments (Table 3).

The Hue results did not differ significantly between the two treatments, demonstrating the lack of a difference in the color of the WSEs (Table 3).

\subsubsection{Biochemical analysis}

The additives used to supplement WSE were responsible for the increase in phenolic compounds and antioxidant capacity (Table 4), as demonstrated by the significant difference in the content of phenolic compounds between pure and supplemented WSE in the two extraction methods. Tocopherol is a monophenolic compound, and the
Table 3 Values of luminosity (L), intensity of red $(+)$ or green (-) represented by index $a^{*}$, intensity of yellow $(+)$ or blue $(-)$ represented by index $b^{*}$, color saturation (Chroma) and chromatic tone
( $\left.{ }^{\circ} \mathrm{Hue}\right)$ followed by standard deviation $(n=3 \pm$ SD) of WSE produced with cultivar BRS-213 by the cold and hot extraction method

\begin{tabular}{llllll}
\hline Method & $L$ & $a^{*}$ & $b^{*}$ & Chroma & ${ }^{\circ}$ Hue \\
\hline Cold & $82.52 \pm 4.57 \mathrm{a}$ & $-0.44 \pm 0.44$ & $17.33 \pm 1.21$ & $17.34 \pm 1.20 \mathrm{~b}$ & $91.41 \pm 1.58$ \\
Hot & $71.81 \pm 0.76 \mathrm{~b}$ & $-0.31 \pm 0.45$ & $21.88 \pm 0.82$ & $21.89 \pm 0.81 \mathrm{a}$ & $90.77 \pm 1.23$ \\
\hline
\end{tabular}

Absence of different letters indicate that there was no significant difference from the $t$ test

Table 4 Comparison of the mean results and standard deviation $(n=3 \pm \mathrm{SD})$ of the phenolic compounds $\left(\mathrm{mg} \mathrm{mL}^{-1}\right)$, flavonoids $\left(\mathrm{mg} \mathrm{mL}^{-1}\right)$ and antioxidant capacity $\left(\mu \mathrm{mol} \mathrm{mL} \mathrm{L}^{-1}\right.$ ) of pure WSE and supplemented with additives, both extracted by the cold and hot extraction method

\begin{tabular}{|c|c|c|c|c|}
\hline \multirow[t]{2}{*}{ Analysis } & \multicolumn{2}{|l|}{ Pure } & \multicolumn{2}{|l|}{ Additives } \\
\hline & Cold & Hot & Cold & Hot \\
\hline Phenolic compounds & $0.69 \mathrm{aB} \pm 0.05$ & $0.50 \mathrm{bB} \pm 0.06$ & $0.77 a A \pm 0.02$ & $0.69 \mathrm{bA} \pm 0.04$ \\
\hline Flavonoids & $0.12 \pm 0.04$ & $0.1 \pm 0.03$ & $0.12 \pm 0.04$ & $0.12 \pm 0.01$ \\
\hline Antioxidant capacity & $0.10 B \pm 0.03$ & $0.05 B \pm 0.02$ & $0.44 A \pm 0.10$ & $0.48 \mathrm{~A} \pm 0.05$ \\
\hline
\end{tabular}

Lowercase letter (in-line) compares the extraction method for pure WSE and for WSE with additives. Capital letter (line) compares the samples (WSE-pure and WSE-with additives) to the same extraction method, from the $t$ test 
apple juice concentrate contains polyphenols such as procyanidin B2, catechins, epicatechins, quercetins and phloridzins [40], substances characterized by their high antioxidant potential.

Flavonoid content was similar regardless of the extraction method of WSE and supplementation with additives (Table 4). Isoflavones are the main flavonoids in soybeans. Quantifying flavonoids, Zhang et al. [41] observed that the hot trituration method was more efficient than cold trituration. This result contradicts that found in this study in which flavonoid content did not differ significantly.

The cold extraction method permitted greater concentration of soluble solids in WSE (Table 2) and a consequently higher phenolic compound content (Table 4) when compared to hot extraction for both pure and supplemented WSEs. However, this higher phenolic content did not result in a difference in antioxidant capacity between the two extraction methods (Table 4).

\subsubsection{Microbiological analysis}

No microorganisms were detected in WSE produced by hot or cold extraction. This result indicates that the most probable number of total and thermotolerant coliforms was less than 3 per $\mathrm{mL}$ of the sample and there was no growth of bacterial, mold or yeast colonies; no colonyforming units were detected. In addition, these results demonstrate that both methods were efficient in eliminating possible microorganisms derived from the raw material (soybean), water, processing tools, environment and/ or handling.

The addition of ascorbic acid and apple juice concentrate, which contains phenolic acids, was responsible for the reduction in the $\mathrm{pH}$ of the WSEs. Thus, the $\mathrm{pH}$ values were lower $(\mathrm{pH} 5.16$ for WSE obtained by cold extraction and $\mathrm{pH} 4.79$ for WSE obtained by hot extraction) than those reported in the literature ( $\mathrm{pH}$ 7.0) for WSE [38]. However, despite this decrease in $\mathrm{pH}$, the amount of organic acids in the sample was not sufficient to eliminate possible microorganisms. A pH below 4.0 is necessary to prevent the growth of decomposing microbes [42]. Thus, the absence of microbial load can be attributed to the soybean processing methods.

\subsubsection{Sensory evaluation of WSE}

The WSE obtained by hot extraction obtained the highest scores of the hedonic scale for all attributes, demonstrating its better acceptance than WSE produced by cold extraction (Table 5). However, Ciabotti et al. [43], using cultivar BRS-213 for the production of WSE by cold extraction, obtained good mean scores for flavor (7.61), indicating that the panelists regularly to very much liked
Table 5 Median of the notes of the WSE attributes produced by the hot and cold extraction method

\begin{tabular}{llllll}
\hline Attributes & \multicolumn{2}{l}{ WSE } & & \multicolumn{2}{l}{ Intensity scale } \\
\cline { 2 - 3 } \cline { 5 - 6 } & \multicolumn{2}{l}{ Hedonic scale } & & Hot & Cold \\
\cline { 2 - 3 } & Hot & Cold & & Ha & $1 \mathrm{a}$ \\
Appearance & $7 \mathrm{a}$ & $6 \mathrm{~b}$ & & $\mathrm{a}$ & $1 \mathrm{a}$ \\
Flavor & $6 \mathrm{a}$ & $5 \mathrm{~b}$ & & $\mathrm{a}$ & $-1 \mathrm{a}$ \\
Sweetness & $6 \mathrm{a}$ & $4 \mathrm{~b}$ & & $\mathrm{a}$ & $-1 \mathrm{a}$ \\
Acidity & $5 \mathrm{a}$ & $4 \mathrm{~b}$ & & $-1 \mathrm{a}$ & $-1 \mathrm{~b}$ \\
Consistency & $5 \mathrm{a}$ & $5 \mathrm{~b}$ & & $0 \mathrm{a}$ & $0 \mathrm{~b}$ \\
Overall rating & $6 \mathrm{a}$ & $5 \mathrm{~b}$ & & $0 \mathrm{a}$ & $0 \mathrm{~b}$ \\
\hline
\end{tabular}

${ }^{*}$ A significance level of 0.05 is considered by the Wilcoxon test. The letters in the line represent the significant differences between the processing methods (hot and cold) for each type of note as hedonic scale (1-9) and intensity ( -2 to 2 ) of each attribute

the WSE. In contrast, the mean flavor score was 3.9 in the present study for WSE obtained by cold extraction (panelists regularly to slightly disliked the beverage).

Rodrigues and Moretti [38] and Ma et al. [4] showed that the higher percentage of protein in soy beverages confers negative sensory properties. This fact explains the preference of the panelists for WSE produced by hot extraction, which had a relatively low protein content (1.2\%) compared to WSE produced by cold extraction (2.6\%).

The WSE obtained by hot extraction was evaluated by the panelists, and $50 \%$ attributed a score higher than 7 to appearance, indicating that they regularly (7) to very much (9) liked the beverage. A score higher than 6 was attributed to aroma, flavor, consistency and overall acceptability, demonstrating that the panelists slightly (6) to very much (9) liked this beverage. The scores were higher than 5 for acidity and sweetness, indicating that part of the panelists rated these attributes of WSE as neutral (5) to very much liked (9).

With respect to WSE obtained by cold extraction, 63\% of the panelists attributed a score less than 4 to flavor, indicating that most of them very much to slightly disliked this beverage.

The intensity test (Table 5) indicated that all assessed attributes of EHS - hot extraction, were intense in the way the tasters liked (note 0 ), with the exception of the sweetness attribute, characterized as somewhat less intense than the tasters liked (note 1), demonstrating that tasters prefer sweeter drinks. In contrast, Brunelli and Venturini Filho [14], who performed sensory evaluation of a mixed soy-grape drink with different concentrations of soluble solids $\left(10,12\right.$ and $\left.14^{\circ} \mathrm{Brix}\right)$, obtained the highest scores for the drink with $14^{\circ} \mathrm{Brix}$. 
The intensity of appearance and aroma of the WSE obtained by cold extraction was slightly higher than appreciated by the panelists, while the intensity of flavor, sweetness and overall acceptability was slightly lower. Only the intensity of acidity and consistency was that liked by the panelists (Table 5). These observations explain the low median scores of the attributes rated on the hedonic scale.

\section{Conclusions}

The gamma radiation doses used did not improve the nutritional composition of the soybean cultivars in terms of their antioxidant potential. None of the doses tested induced an increase in flavonoid content or antioxidant capacity. Only phenolic compounds increased in the BRS213 and BRS-258 cultivars when irradiated with the dose of $4 \mathrm{kGy}$ or higher. Furthermore, oxidant and antioxidant enzymes remained stable, except for SOD of cultivar BRS213 whose activity decreased when irradiated with the dose of $8 \mathrm{kGy}$.

Although WSE produced by the cold extraction method exhibited better nutritional quality (higher protein, lipid and phenolic content), the WSE obtained by hot extraction had better organoleptic properties. There was no difference in color, flavonoid content or antioxidant capacity between the extraction methods. In view of the differences between the results of the processing methods, we recommend the use of hot extraction to obtain WSE since only this method provided sensory acceptance by the panelists.

\section{Compliance with ethical standards}

Conflict of interest The author(s) declare that they have no conflict of interest.

\section{References}

1. Popović BM, Štajner D, Mandić A et al (2013) Enhancement of antioxidant and isoflavones concentration in gamma irradiated soybean. Sci World J 2013:1-5. https://doi. org/10.1155/2013/383574

2. Dixit AK, Bhatnagar D, Kumar V et al (2010) Gamma irradiation induced enhancement in isoflavones, total phenol, anthocyanin and antioxidant properties of varying seed coat colored soybean. J Agric Food Chem 58:4298-4302. https://doi. org/10.1021/jf904228e

3. Prabhakaran MP, Perera CO (2006) Effect of extraction methods and UHT treatment conditions on the level of isoflavones during soymilk manufacture. Food Chem 99:231-237. https://doi. org/10.1016/j.foodchem.2005.06.055
4. Ma L, Li B, Han F et al (2015) Evaluation of the chemical quality traits of soybean seeds, as related to sensory attributes of soymilk. Food Chem 173:694-701. https://doi.org/10.1016/j. foodchem.2014.10.096

5. Comarella CG, Sautter CK, Ebert LC, Penna NG (2012) Polifenóis totais e avaliação sensorial de suco de uvas Isabel tratadas com ultrassom. Braz J Food Technol 15:69-73. https://doi. org/10.1590/S1981-67232012005000042

6. Plaza L, Sánchez-Moreno C, Elez-Martínez P et al (2006) Effect of refrigerated storage on vitamin $\mathrm{C}$ and antioxidant activity of orange juice processed by high-pressure or pulsed electric fields with regard to low pasteurization. Eur Food Res Technol 223:487-493. https://doi.org/10.1007/s00217-005-0228-2

7. Filho TL, Teixeira LJQ, Da Rocha CT et al (2012) Energia ionizante na conservação de alimentos: revisão. Bol do Cent Pesqui Process Aliment 30:243-254. https://doi.org/10.5380/cep. v30i2.30501

8. Zhong K, Hu X, Zhao G et al (2005) Inactivation and conformational change of horseradish peroxidase induced by pulsed electric field. Food Chem 92:473-479. https://doi. org/10.1016/j.foodchem.2004.08.010

9. de Barros ÉA, Broetto F, Bressan DF et al (2014) Chemical composition and lipoxygenase activity in soybeans (Glycine max L. Merr.) submitted to gamma irradiation. Radiat Phys Chem 98:29-32. https://doi.org/10.1016/j.radphyschem.2013.12.040

10. Sakhale BK, Pawar VN (2012) Studies on the development and storage of whey based RTS beverage from Mango cv. Kesar. J Food Process Technol. https://doi.org/10.4172/21577110.1000148

11. Maia MJL, Rossi EA, de Carvalho MRB (2006) Qualidade e rendimento do "leite" de soja da unidade de produção de derivados da soja. Aliment Nutr 17:65-72

12. Howell RW, Caldwell BE (1978) Genetic and other biological characteristics. In: Smith AK, Circle SJ (eds) Soybeans: chemistry and technology. AVI Publishing Co, Westport, pp 27-60

13. Nelson Al, Steinberg MP, Wei LS (1976) Illinois process for separation of soymilk. J Food Sci 41:57-61

14. Brunelli LT, Venturini Filho WG (2012) Caracterização química e sensorial de bebida mista de soja e uva. Aliment Nutr 23:467-473

15. Giannopolitis CN, Ries SK (1977) Superoxide dismutases: I. Occurrence in higher plants. Plant Physiol 59:309-314. https ://doi.org/10.1104/pp.59.2.309

16. Clemente E, Pastore GM (1998) Peroxidase and polyphenoloxidase, the importance for food technology. Ciênc Tecnol Aliment 32:167-171

17. Robinson DS (1987) Food Biochemistry and nutritional value. Logman Scientific and Technical, London

18. Wettasinghe M, Shahidi $F$ (1999) Evening primrose meal: a source of natural antioxidants and scavenger of hydrogen peroxide and oxygen-derived free radicals. J Agric Food Chem 47:1801-1812

19. Vennat B, Gross D, Pourrat AP (1992) Hamamelis virginiana: identification and assay of proanthocyanidins, phenolic acids and flavonoids in leaf extracts. PharmActa Helv 67:11-14

20. Brand-Williams W, Cuvelier ME, Berset C (1995) Use of a free radical method to evaluate antioxidant activity. LWT Food Sci Technol 28:25-30. https://doi.org/10.1016/S0023 -6438(95)80008-5

21. BRASIL. Ministério da Saúde. Agência Nacional de Vigilância Sanitária (2005) Métodos físico-químicos para análise de alimentos, 4th edn. Instituto Adolfo Lutz, São Paulo

22. Konica Minolta (1998) Precise color Communication: Color control from perception to instrumentation. In: KONICA MINOLTA Sens. http://www.konicaminolta.com. Accessed 6 Jun 2019 
23. Silva N, Junqueira VCA, Silveira NFA (2001) Manual de Métodos de Análises Microbiológicas de Alimentos, 2nd edn. Livraria Varela, São Paulo

24. ABNT. Associação Brasileira de Normas Técnicas (1998) NBR 14141: Escalas utilizadas em análise sensorial de alimentos e bebidas

25. Chaves JBP, Sproesser RL (1999) Práticas de laboratório de análise sensorial de alimentos e bebidas. UFV, Viçosa

26. Pagano M, Gauvrea UK (2004) Princípios de Bioestatística. Ed Thompson

27. Kumar V, Rani A, Goyal L et al (2010) Sucrose and raffinose family oligosaccharides (RFOs) in soybean seeds as influenced by genotype and growing location. J Agric Food Chem 58:5081-5085. https://doi.org/10.1021/jf903141s

28. Bhat R, Sridhar KR, Tomita-Yokotani K (2007) Effect of ionizing radiation on antinutritional features of velvet bean seeds (Mucuna pruriens). Food Chem 103:860-866. https://doi. org/10.1016/j.foodchem.2006.09.037

29. Toledo TC, Canniatti-Brazaca SG, Arthur V, Piedade SMS (2007) Effects of gamma radiation on total phenolics, trypsin and tannin inhibitors in soybean grains. Radiat Phys Chem 76:16531656. https://doi.org/10.1016/j.radphyschem.2007.02.001

30. López-Gutiérrez N, Romero-González R, Garrido Frenich A, Martínez Vidal JL (2014) Identification and quantification of the main isoflavones and other phytochemicals in soy based nutraceutical products by liquid chromatography-orbitrap high resolution mass spectrometry. J Chromatogr A 1348:125-136. https://doi.org/10.1016/j.chroma.2014.04.090

31. Verardo V, Riciputi Y, Garrido-Frenich A, Caboni MF (2015) Determination of free and bound phenolic compounds in soy isoflavone concentrate using a PFP fused core column. Food Chem 185:239-244. https://doi.org/10.1016/j.foodchem.2015.03.090

32. Dixit AK, Bhatnagar D, Kumar V et al (2012) Antioxidant potential and radioprotective effect of soy isoflavone against gamma irradiation induced oxidative stress. J Funct Foods 4:197-206. https://doi.org/10.1016/j.jff.2011.10.005

33. Tewari K, Kumari S, Vinutha T et al (2014) Gamma irradiation induces reduction in the off-flavour generation in soybean through enhancement of its antioxidant potential. J Radioanal Nucl Chem. https://doi.org/10.1007/s10967-014-3803-9

34. Alikamanoglu S, Yaycili O, Sen A (2011) Effect of gamma radiation on growth factors, biochemical parameters, and accumulation of trace elements in soybean plants (Glycine max L. Merrill). Biol Trace Elem Res 141:283-293. https://doi. org/10.1007/s12011-010-8709-y

35. De Freitas AA, Francelin MF, Hirata GF et al (2008) Atividades das enzimas peroxidase (POD) e polifenoloxidase (PPO) nas uvas das cultivares benitaka e rubi e em seus sucos e geléias. Ciência Tecnol Aliment 28:172-177. https://doi.org/10.1590/S0101-20612 008000100025

36. Axelrod B, Cheesbrough TM, Laakso S (1981) Lipoxygenase from soybeans. Methods Enzymol 71:441-451

37. Giri SK, Mangaraj S (2012) Processing influences on composition and quality attributes of soymilk and its powder. Food Eng Rev 4:149-164. https://doi.org/10.1007/s12393-012-9053-0

38. Rodrigues RDS, Moretti RH (2008) Caracterização Físico-Química de Bebida Protéica Elaborada com Extrato de Soja e Polpa de Pêssegos. Bol CEPPA 26:101-110

39. Nunes JS, De Sousa EP, De Castro DS et al (2014) Avaliação do perfil físico e reológico de bebida de soja sabor iogurte com polpa de morango. Rev Verde Agroecol e Desenvolv Sustentável 9:229-233

40. Will F, Bauckhage K, Dietrich H (2000) Apple pomace liquefaction with pectinases and cellulases: analytical data of the corresponding juices. Eur Food Res Technol 211:291-297. https:// doi.org/10.1007/s002170000171

41. Zhang Y, Chang SKC, Liu Z (2015) Isoflavone profile in soymilk as affected by soybean variety, grinding, and heatprocessing methods. J Food Sci 80:C983-C988. https://doi. org/10.1111/1750-3841.12839

42. Forsythe SJ (2002) Microbiologia da segurança alimentar. Tradução de Maria Carolina Minardi Guimarães; Cristina Leonhardt. Artmed, Porto Alegre

43. Ciabotti S, Barcelos MdFP, Pinheiro ACM et al (2007) Características sensoriais e físicas de extratos e tofus de soja comum processada termicamente e livre de lipoxigenase. Ciência Tecnol Aliment 27:643-648. https://doi.org/10.1590/S0101-20612 007000300033

Publisher's Note Springer Nature remains neutral with regard to jurisdictional claims in published maps and institutional affiliations. 